\title{
Data report: permeability of Expedition 344 sediments from the Costa Rica Seismogenesis Project ${ }^{1}$
}

\author{
Stephanie R. James, ${ }^{2}$ and Elizabeth J. Screaton ${ }^{2}$
}

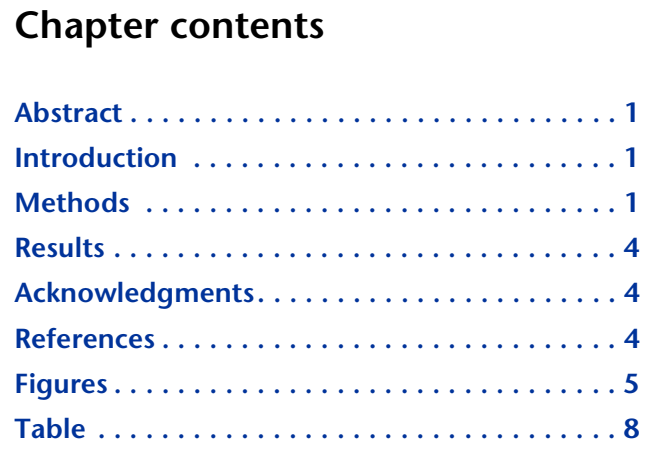

'James, S.R., and Screaton, E.J., 2015. Data report: permeability of Expedition 344 sediments from the Costa Rica Seismogenesis Project. In Harris, R.N., Sakaguchi, A., Petronotis, K., and the Expedition 344 Scientists, Proceedings of the Integrated Ocean Drilling Program, 344: College Station, TX (Integrated Ocean Drilling Program). doi:10.2204/iodp.proc.344.202.2015

${ }^{2}$ Department of Geological Sciences, University of Florida, Gainesville FL 32611, USA.

Correspondence author:

screaton@ufl.edu

\begin{abstract}
Permeability tests were conducted on 17 core samples (oriented vertically) and 1 minicore sample (oriented horizontally) from Integrated Ocean Drilling Program Expedition 344, which investigated the processes affecting seismogenesis of the Costa Rica subduction zone. Fifteen of the samples consisted of clastic sediment and three samples consisted of calcareous ooze. Measured vertical permeability varies from $5.4 \times 10^{-19} \mathrm{~m}^{2}$ to $1.3 \times 10^{-15} \mathrm{~m}^{2}$. Grain sizes were measured for 11 of the core samples. Samples consisted primarily of clay-sized $(<4 \mu \mathrm{m})$ fractions $(53-77 \mathrm{wt} \%)$, with lesser silt-sized (4 to $63 \mu \mathrm{m})$ fractions $(22-41 \mathrm{wt} \%)$ and sand-sized (>63 $\mu \mathrm{m})$ fractions (1-19 wt $\%)$.
\end{abstract}

\section{Introduction}

Integrated Ocean Drilling Program (IODP) Expedition 344 is the second expedition of the Costa Rica Seismogenesis Project (CRISP). The primary objective of Expeditions 334 and 344 was to investigate the processes that control seismic rupture at erosive plate boundaries. Expedition 344 recovered cores from offshore the Osa Peninsula of Costa Rica (Fig. F1). In this study, we used flow-through permeability tests to measure the permeability of core samples from Sites U1380 and U1381 and Sites U1412U1414 (Fig. F2). Grain size analyses were conducted on a subset of the samples to characterize the fraction of sand-, silt-, and claysized particles. The purpose of these measurements is to help construct permeability-porosity relationships (e.g., Daigle and Screaton, 2015) for use in modeling of fluid flow and pore pressure generation.

\section{Methods}

\section{Permeability tests}

Permeability tests were conducted using the Trautwein Soil Testing Equipment Company's DigiFlow K (Fig. F3). The equipment consists of a cell (to contain the sample and provide isostatic effective stress) and three pumps (sample top pump, sample bottom pump, and cell pump). American Society for Testing and Materials (ASTM) designation D5084-90 (ASTM International, 1990) was used as a guideline for general procedures. Deionized water was used as the fluid in the pumps while an idealized solution of $33 \mathrm{~g}$ 
$\mathrm{NaCl}$ per liter of water permeates the sample. Pressure is transmitted from the deionized water to the permeant across a rubber membrane in an interface chamber (Fig. F3).

Retrieved core samples from Expedition 344 were stored in plastic core liners and sealed in aluminum bags to prevent moisture loss. The sealed samples were stored in the refrigerator at $4^{\circ} \mathrm{C}$ until immediately prior to sample preparation. Most of the tests (17 samples) were conducted with flow in the vertical direction (along the axis of the core) using the whole-round core. A single minicore sample (344U1414A-44R-1W, 53-55 cm) was oriented perpendicular to the core axis. The samples were carefully inspected for cracking or disturbance; two fractured or damaged samples were not tested. To provide freshly exposed surfaces, cores were trimmed on both ends using an Exacto knife, wire saw, or utility knife, depending on core properties. After trimming the ends of the sample, the diameter and height of the sample were measured. Diameters of the trimmed wholeround cores ranged from 5.3 to $6.6 \mathrm{~cm}$. Sample heights ranged from 4.45 to $13.7 \mathrm{~cm}$. The sample was then placed in a rubber membrane and fitted with saturated porous disks and end caps. Next, the sample was placed in the cell, which was filled with deionized water. The membrane-encased sample was subjected to the applied pressure of the water in the cell, but fluid exchange occurs only through the flow lines connecting the end caps to the top and bottom pumps. A small confining pressure of $\sim 0.03 \mathrm{MPa}$ (5 psi) was applied, and flow lines were flushed to remove any trapped air bubbles. After flushing the flow lines, the sample was backpressured to either $\sim 0.28$ or $\sim 0.41 \mathrm{MPa}$ (40 or $60 \mathrm{psi}$, respectively).

Backpressure was achieved by concurrently ramping the cell and sample pressure to maintain a steady effective stress of $0.03 \mathrm{MPa}$ (5 psi). Backpressure was maintained at least $24 \mathrm{~h}$. Subsequently, cell fluid pressure was increased while sample backpressure was maintained, thus increasing the effective stress on the sample. This effective stress both consolidates the sample and pushes the flexible membrane against the sample to prevent flow bypassing the sample. If the membrane is not pressed against the sample it would be possible for water from the flow lines to bypass the sample by running through the space between the membrane and the core. This would result in an erroneously large permeability estimate.

Because the whole-round samples were sealed immediately after cutting the core liner, the samples were expected to be near saturation prior to testing. Backpressuring at $0.28 \mathrm{MPa}$ (40 psi) for $\sim 24 \mathrm{~h}$ is sufficient to ensure full saturation under these conditions
(ASTM International, 1990). A B-test on each sample was implemented for the last 12 samples tested. In a B-test, the cell confining pressure was instantaneously increased by 10 psi and the sample response was measured. For saturated samples, this yields the Skempton B-coefficient. For soft to medium clays, the Skempton B-coefficient is nearly 1 (Wang, 2000), and a B-test result $>95 \%$ is typically used to indicate saturation. This criteria is not applicable for more consolidated materials, as compiled B-coefficients for mudstone, sandstone, and limestone are 95\%, 50\% to $88 \%$, and $25 \%$, respectively (Wang, 2000). Samples with B-coefficients below 95\% were either given additional time for saturation or increased backpressure. Saturation was assumed if the B-value did not change with increased time or backpressure.

For each sample location, in situ effective stress was estimated for hydrostatic conditions using the shipboard bulk density measurements of the overlying sediments. Effective stress increments between depths of shipboard measurements were calculated assuming hydrostatic fluid pressures and summed. The estimated in situ effective stress is generally much greater than what was reached in the laboratory testing. Thus these permeability values should not be assumed to reflect in situ conditions. As noted above, the purpose of the measurements was to construct permeability-porosity relationships for use in fluid-flow modeling.

Once the target effective stress was achieved, cell pressure and backpressure were maintained. The sample was allowed to equilibrate for at least $12 \mathrm{~h}$ and generally $24 \mathrm{~h}$. Throughout testing, inflows and outflows to the cell fluid were monitored to assess changes in sample volume, and sample data were recorded every minute. Since fluid pressure in the closed hydraulic system was affected by temperature changes, testing was conducted within a closed cabinet to keep the internal temperature uniform. Testing temperatures were $28^{\circ} \pm 1^{\circ} \mathrm{C}$. Two or more flow tests were performed at each effective stress level, with flow direction varied between tests. Flow tests were run by specifying pressures of the top and bottom pump and recording flow rates into and out of the sample.

The pressure difference, $\Delta P$, from the top and bottom pumps was converted to hydraulic head difference $(\Delta h)$ :

$$
\Delta h=\Delta P / \rho_{\mathrm{f}} \mathrm{g},
$$

where $\rho_{\mathrm{f}}$ is fluid density $\left(1021 \mathrm{~kg} / \mathrm{m}^{3}\right)$ and $\mathrm{g}$ is acceleration due to gravity $\left(9.81 \mathrm{~m} / \mathrm{s}^{2}\right)$.

We used the measured flow rate, cross-sectional area of the sample, and the calculated head difference be- 
tween the top and bottom of the sample to calculate the hydraulic conductivity using Darcy's law:

$$
Q=-K A(\Delta h / \Delta l),
$$

where

$$
\begin{aligned}
Q= & \text { measured flow rate in cubic meters per sec- } \\
& \text { ond, } \\
K= & \text { hydraulic conductivity in meters per second, } \\
A= & \text { the cross-sectional area of the sample in } \\
& \text { square meters, } \\
\Delta h= & \text { hydraulic head difference across the sample } \\
& \text { in meters, and } \\
\Delta l= & \text { the length of the sample in meters. }
\end{aligned}
$$

The hydraulic conductivity values were then converted to permeability (in square meters) using

$$
k=(K \mu) /(\rho g),
$$

where

$$
\begin{aligned}
& \rho=\text { fluid density }\left(1021 \mathrm{~kg} / \mathrm{m}^{3}\right), \\
& g=\text { acceleration due to gravity }\left(9.81 \mathrm{~m} / \mathrm{s}^{2}\right) \text {, and } \\
& \mu=\text { viscosity }(0.000893 \mathrm{~Pa} \cdot \mathrm{s}) .
\end{aligned}
$$

For laboratory temperature (averaging $28^{\circ} \mathrm{C}$ ) and fluid salinity $(33 \mathrm{~g} / \mathrm{L})$, a fluid density of $1021 \mathrm{~kg} / \mathrm{m}^{3}$ and viscosity of $0.000893 \mathrm{~Pa} \cdot \mathrm{s}$ were calculated based on relationships compiled by Sharqawy et al. (2010). Assuming a reasonable water compressibility, density change caused by the applied pressure is minor $(<0.1 \%)$. A $1 \mathrm{~h}$ interval of stable flow rates was averaged for the permeability calculations, and the standard deviation of the permeability during that interval was calculated to assess uncertainty. The fluctuations in the calculated permeability are likely caused by slight temperature variations. The resulting volume changes would cause temporary changes in measured flow rates. The time interval was selected based on where inflow best matched outflow, indicating steady-state conditions, and where the standard deviation was minimized.

For every sample, up to three effective stress steps were performed. The corresponding porosity for each effective stress was calculated using the change in volume of fluid $(\mathrm{mL})$ contained in the cell during each consolidation step. The volume change during consolidation is assumed to be solely due to changes in sample porosity. Influences from material and apparatus stiffness are assumed to be negligible. Total sample volume $\left(V_{\mathrm{T}(0)}\right)$ was calculated using $\pi r^{2} \mathrm{~h}$, where $r$ is the radius of the core sample and $h$ is the height of the sample. Initial porosities $\left(n_{0}\right)$ for volume calculations were obtained from the shipboard moisture and density results of samples taken adjacent to each permeability sample. We assumed that the porosity of the sample at the end of backpressure is similar to the $n_{0}$ of the sample due to the small change in effective stress (0.03 MPa).

Using $n_{0}$, the volume of voids before the testing $\left(V_{\mathrm{v}(0)}\right)$ was calculated using

$$
V_{\mathrm{v}(0)}=n_{0} V_{\mathrm{T}(0)} .
$$

Volume of solids $\left(V_{\mathrm{s}}\right)$ was calculated using

$$
V_{\mathrm{S}}=V_{\mathrm{T}(0)}-V_{\mathrm{v}(0)}
$$

Using the difference of cell volumes between two consecutive steps (e.g., cell volume at backpressure and cell volume at first consolidation), the change in volume of water in the cell $\left(\Delta V_{\mathrm{T}(1)}\right)$ was calculated. The new total volume of the sample $\left(V_{\mathrm{T}(1)}\right)$ after pore spaces were reduced during the consolidation process was determined by subtracting the change in cell volume at the end of the consolidation step $\left(\Delta V_{\mathrm{T}(1)}\right)$ from the total sample volume $\left(V_{\mathrm{T}(0)}\right)$ :

$$
V_{\mathrm{T}(1)}=V_{\mathrm{T}(0)}-\Delta V_{\mathrm{T}(1)} .
$$

Using the calculated new total volume of the sample $\left(V_{\mathrm{T}(1)}\right)$, the new porosity at the end of the consolidation is calculated. The new porosity $\left(n_{1}\right)$ at the end of the consolidation is

$$
n_{1}=\left(V_{\mathrm{T}(1)}-V_{\mathrm{S}}\right) / V_{\mathrm{T}(1)} .
$$

\section{Grain size analyses}

Eleven of the 17 permeability samples were selected to represent various lithologies and were analyzed for grain size distribution. Subsamples for quantitative grain size analyses were extracted in $1.5 \mathrm{~cm}$ thick intervals from the sample after completion of the permeability tests. The subsamples were homogenized and disaggregated in a solution of sodium hexametaphosphate (Calgon) to inhibit clay flocculation. Subsamples were also immersed in an ultrasonic bath for a minimum of $2 \mathrm{~h}$ to assist disaggregation. A small aliquot of the homogenized sample was dried to determine water content, which was then used to establish the equivalent dry mass used in the particle size analysis. Once disaggregated, a subsample was wet-sieved at $63 \mu \mathrm{m}$ to determine the sandsized fraction. A separate sample was wet-sieved at $53 \mu \mathrm{m}$, and material $<53 \mu \mathrm{m}$ was analyzed on a 5100 Micrometrics SediGraph (Coakley and Syvitski, 1991). The SediGraph emits X-rays that record the settling rates of particles suspended in a Calgon solution. The principle of Stoke's law is then used to calculate grain sizes. The SediGraph data were combined with the wet-sieve results to normalize the 
mud and sand fraction to their relative masses to determine the proportion of sand, silt, and clay size particles.

\section{Results}

Table T1 summarizes the effective stress and estimated porosity and permeability at each consolidation step as well as the grain size distribution for selected samples. Measured vertical permeabilities vary from $5.4 \times 10^{-19} \mathrm{~m}^{2}$ to $1.3 \times 10^{-15} \mathrm{~m}^{2}$. All samples were dominated by clay-sized particles, ranging between 53 and $77 \mathrm{wt} \%$. The secondary grain size for all samples were silt-sized particles, ranging between 22 and $41 \mathrm{wt} \%$. Sand-sized particles make up the smallest grain size fraction, ranging between 1 and $19 \mathrm{wt} \%$.

\section{Acknowledgments}

This research used samples and data provided by the Integrated Ocean Drilling Program (IODP). Funding for this research was provided by a Consortium for Ocean Leadership U.S. Scientist Support Program postcruise grant to E. Screaton and National Science Foundation grant EAR-0819769. The authors thank reviewer Brandon Dugan, John Jaeger of University of Florida for expertise and equipment for grain size analyses, and James Sutton and Lanie Meridith for assistance with sample analysis.

\section{References}

ASTM International, 1990. Standard test method for measurement of hydraulic conductivity of saturated porous materials using a flexible wall permeameter (Standard D5084-90). In Annual Book of ASTM Standards: Philadelphia (Am. Soc. Testing Mater.), 63-70.

Coakley, J.P., and Syvitski, J.P.M., 1991. SediGraph technique. In Syvitski, J.P.M. (Ed.), Principles, Methods, and Application of Particle Size Analysis: Cambridge, UK (Cambridge Univ. Press), 129-142. http://dx.doi.org/ 10.1017/CBO9780511626142.013

Daigle, H., and Screaton, E.J., 2015. Evolution of sediment permeability during burial and subduction. Geofluids, 15(1-2):84-105. http://dx.doi.org/10.1111/gfl.12090

Harris, R.N., Sakaguchi, A., Petronotis, K., Baxter, A.T., Berg, R., Burkett, A., Charpentier, D., Choi, J., Diz Ferreiro, P., Hamahashi, M., Hashimoto, Y., Heydolph, K., Jovane, L., Kastner, M., Kurz, W., Kutterolf, S.O., Li, Y., Malinverno, A., Martin, K.M., Millan, C., Nascimento, D.B., Saito, S., Sandoval Gutierrez, M.I., Screaton, E.J., Smith-Duque, C.E., Solomon, E.A., Straub, S.M., Tanikawa, W., Torres, M.E., Uchimura, H., Vannucchi, P., Yamamoto, Y., Yan, Q., and Zhao, X., 2013. Expedition 344 summary. In Harris, R.N., Sakaguchi, A., Petronotis, K., and the Expedition 344 Scientists, Proceedings of the Integrated Ocean Drilling Program, 344: College Station, TX (Integrated Ocean Drilling Program). http:// dx.doi.org/10.2204/iodp.proc.344.101.2013

Sharqawy, M.H., Lienhard, J.H., V, and Zubair, S.M., 2010. Thermophysical properties of seawater: a review of existing correlations and data. Desalination and Water Treatment, 16(1-3):354-380. http://dx.doi.org/ 10.5004/dwt.2010.1079

Wang, H.F., 2000. Theory of Linear Poroelasticity with Applications to Geomechanics and Hydrogeology: Princeton, N.J. (Princeton Univ. Press).

Acceptance: 1 October 2015

Publication: 14 December 2015

MS 344-202 
Figure F1. Location of Expedition 344 drill sites.

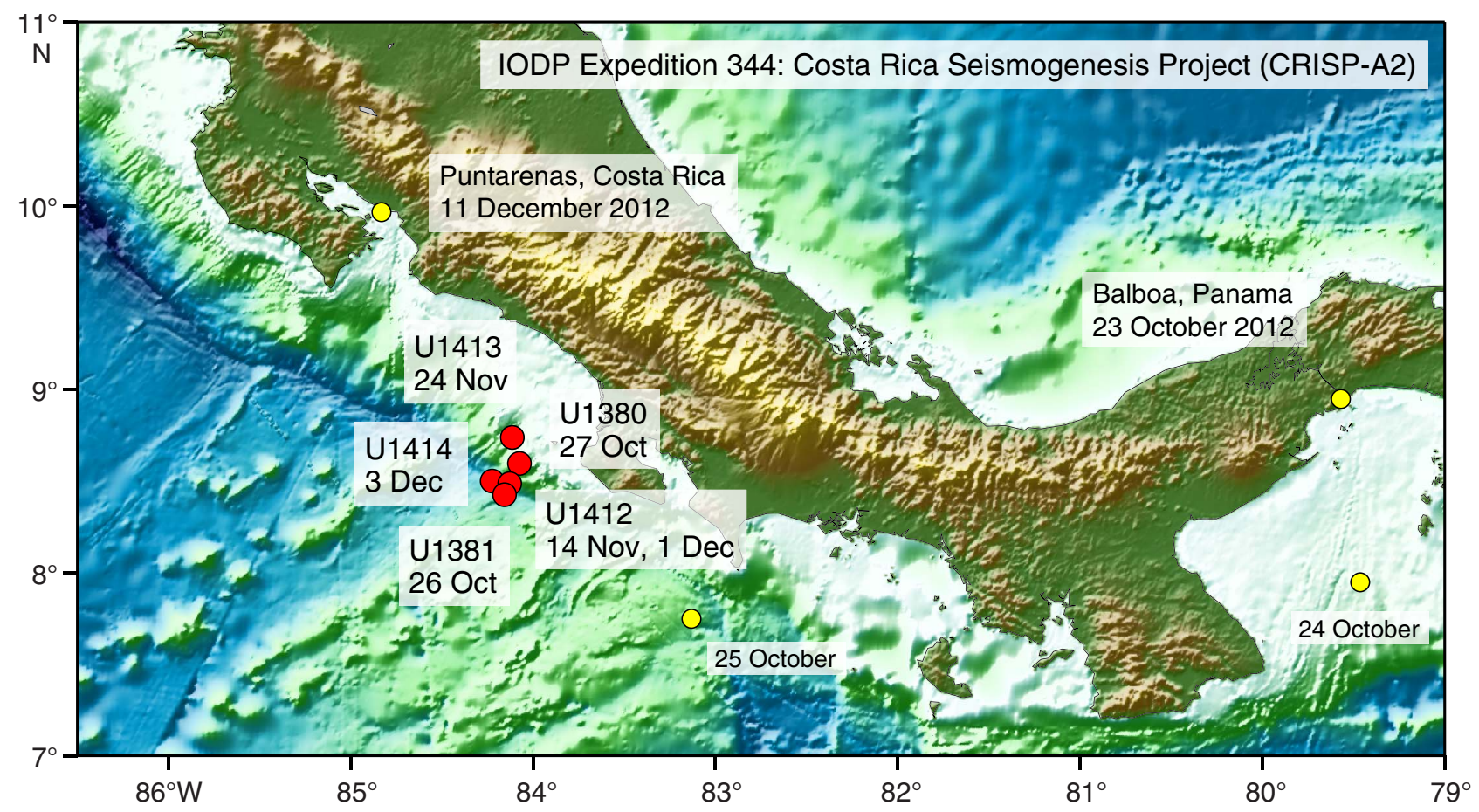


Figure F2. Shipboard porosity results, lithologic unit boundaries (from Harris et al., 2013), and sample locations. Sample locations are marked with symbols corresponding to permeability and grain size results (solid squares) or just permeability results (open squares) listed in Table T1. A. Units I-III are described as silty clay with fine sandstone, clayey siltstone with medium to coarse sandstone, and silty claystone, respectively. B. Units I-III are described as silty clay to clay, nannofossil calcareous ooze with sponge spicules, and nannofossil ooze, respectively. C. Units I-III are described as calcareous clay with minor silt and silty clay, calcareous ooze with nannofossils and biogenic silica, and clayey siltstone with sandstone, respectively. D. Units I-III are described as silty clay with fine sand, calcareous clayey silt(stone) and minor sand(stone), and fine- to mediumgrained sandstone and siltstone, respectively. E. Units I-III are described as silty clay with sand to calcareous nannofossil-rich clay, nannofossil calcareous ooze with sponge spicules, and calcareous and siliceous cemented silt- and sandstone, respectively.
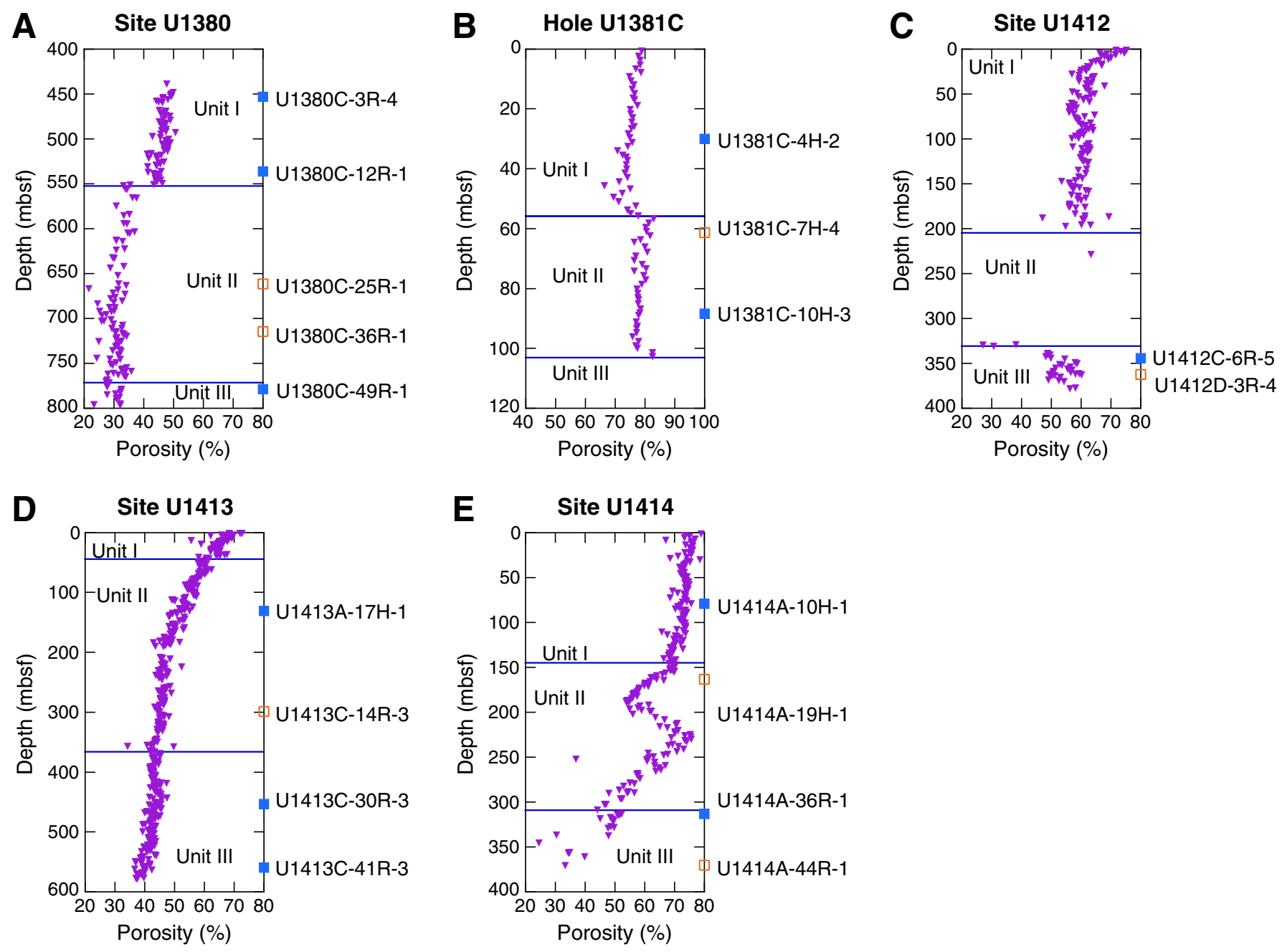
Figure F3. Permeability test system. The top, bottom, and cell pumps from Geotac consist of $80 \mathrm{~mL}$ pistons that are moved upward or downward to infuse or extract water from the sample or cell. The interface chamber has a rubber diaphragm in the center to separate the seawater that is used as a permeant (bottom chamber) from the deionized water (DI) used in the pumps (top chamber). Deionized water is used in the cell pump and in the sample cell, which has a volume of $2300 \mathrm{~mL}$.
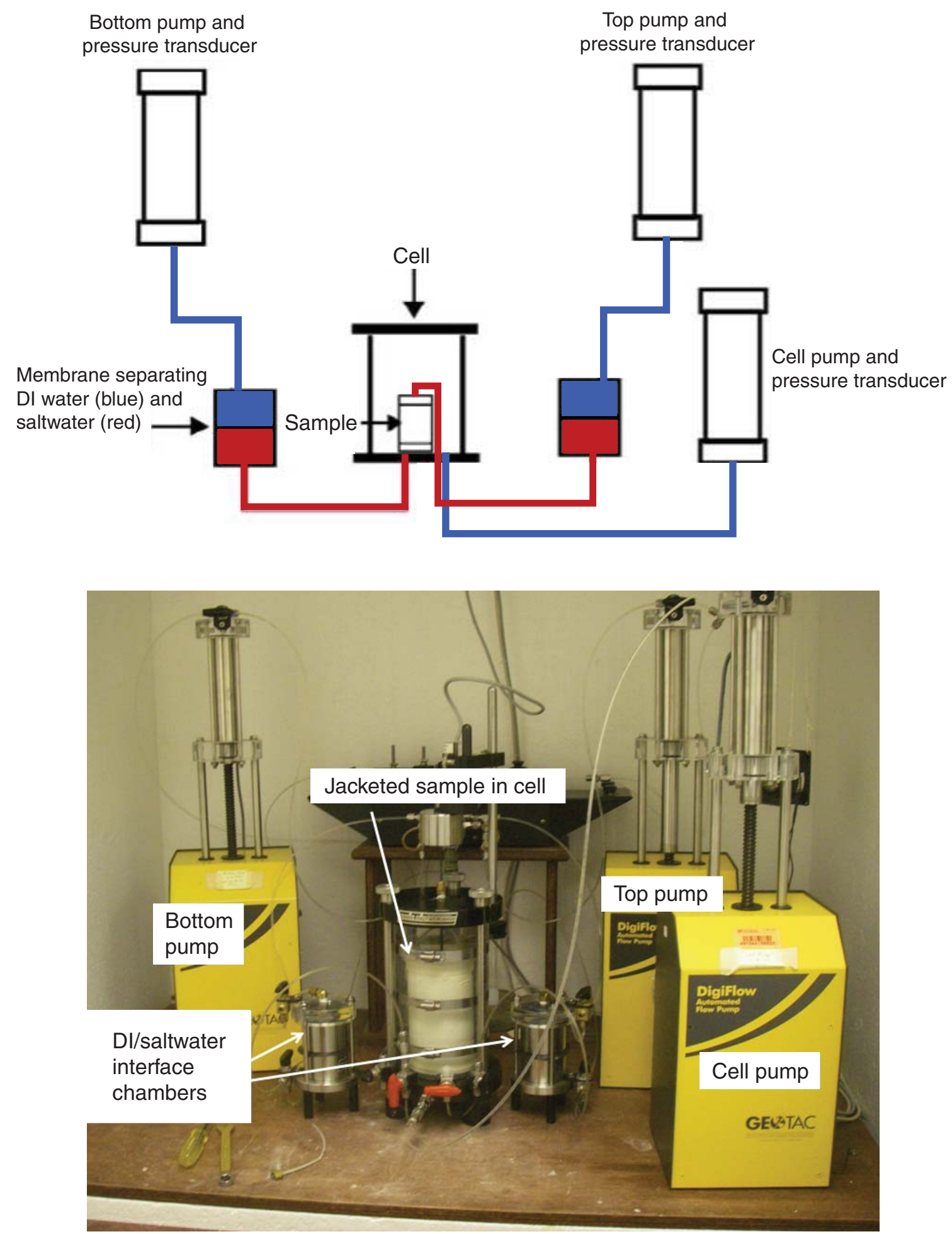


\begin{tabular}{|c|c|c|c|c|c|c|c|c|c|c|c|c|c|}
\hline \multirow{2}{*}{$\begin{array}{l}\text { Core, section, } \\
\text { interval }(\mathrm{cm})\end{array}$} & \multirow{2}{*}{$\begin{array}{c}\text { Top } \\
\text { depth } \\
\text { (mbsf) }\end{array}$} & \multirow[b]{2}{*}{ Lithostratigraphic unit description } & \multirow{2}{*}{$\begin{array}{l}\text { Shipboard } \\
\text { porosity } \\
\text { (\%) }\end{array}$} & \multirow{2}{*}{$\begin{array}{l}\text { Est. in situ } \\
\text { effective } \\
\text { stress } \\
(\mathrm{MPa})\end{array}$} & \multirow{2}{*}{$\begin{array}{l}\text { Effective } \\
\text { stress } \\
\text { during } \\
\text { testing } \\
(\mathrm{MPa})\end{array}$} & \multirow{2}{*}{$\begin{array}{l}\text { B-test } \\
\text { results } \\
(\%)\end{array}$} & \multirow{2}{*}{$\begin{array}{l}\text { Porosity } \\
\text { during } \\
\text { testing } \\
(\%)\end{array}$} & \multirow{2}{*}{$\begin{array}{l}\text { Number of } \\
\text { flow tests }\end{array}$} & \multirow{2}{*}{$\begin{array}{l}\text { Permeability } \\
\left(\mathrm{m}^{2}\right)\end{array}$} & \multirow{2}{*}{$\begin{array}{l}\text { Permeability } \\
\text { standard } \\
\text { deviation } \\
\left(\mathrm{m}^{2}\right)\end{array}$} & \multicolumn{3}{|c|}{ Grain size (wt\%) } \\
\hline & & & & & & & & & & & Sand & Silt & Clay \\
\hline \multicolumn{14}{|l|}{ 344-U1380C- } \\
\hline $3 R-4$ & 453.07 & Silty clay with fine sandstone & 49.3 & 3.82 & 0.28 & 93 & 47.0 & 2 & $7.58 \mathrm{E}-19$ & $4.64 \mathrm{E}-20$ & 3 & 38 & 59 \\
\hline $12 \mathrm{R}-1$ & 536.38 & Silty clay with fine sandstone & 45.9 & 4.56 & 0.14 & 95 & 44.7 & 3 & $1.21 \mathrm{E}-17$ & 4.37E-20 & 2 & 29 & 69 \\
\hline $12 \mathrm{R}-1$ & 536.38 & Silty clay with fine sandstone & 45.9 & 4.56 & 0.34 & 95 & 42.0 & 3 & $2.34 \mathrm{E}-18$ & $5.10 \mathrm{E}-20$ & 2 & 29 & 69 \\
\hline $12 \mathrm{R}-1$ & 536.38 & Silty clay with fine sandstone & 45.9 & 4.56 & 0.55 & 95 & 38.0 & 4 & $1.41 \mathrm{E}-18$ & $2.79 \mathrm{E}-20$ & 2 & 29 & 69 \\
\hline $25 R-1$ & 661.48 & Clayey siltstone with medium to coarse sandstone & 31.6 & 5.88 & 0.21 & 95 & 28.0 & 5 & $2.98 \mathrm{E}-18$ & $7.94 \mathrm{E}-20$ & NT & NT & NT \\
\hline $25 \mathrm{R}-1$ & 661.48 & Clayey siltstone with medium to coarse sandstone & 31.6 & 5.88 & 0.41 & 95 & 27.0 & 5 & $2.94 \mathrm{E}-18$ & 1.09E-19 & NT & NT & NT \\
\hline $36 \mathrm{R}-1$ & 714.50 & Clayey siltstone with medium to coarse sandstone & 30.8 & 6.49 & 0.21 & 95 & 28.0 & 4 & $1.94 \mathrm{E}-18$ & $5.30 \mathrm{E}-20$ & NT & NT & NT \\
\hline $36 \mathrm{R}-1$ & 714.50 & Clayey siltstone with medium to coarse sandstone & 30.8 & 6.49 & 0.41 & 95 & 26.0 & 4 & 1.10E-18 & 4.97E-20 & NT & NT & NT \\
\hline $49 \mathrm{R}-1$ & 779.04 & Silty claystone with fine sandstone & 32.4 & 7.21 & 0.14 & NT & 31.0 & 2 & $1.56 \mathrm{E}-18$ & $4.35 \mathrm{E}-20$ & 3 & 31 & 66 \\
\hline $49 \mathrm{R}-1$ & 779.04 & Silty claystone with fine sandstone & 32.4 & 7.21 & 0.28 & NT & 30.0 & 4 & $6.99 \mathrm{E}-19$ & 4.57E-20 & 3 & 31 & 66 \\
\hline 49R-1 & 779.04 & Silty claystone with fine sandstone & 32.4 & 7.21 & 0.41 & NT & 29.0 & 3 & $5.42 \mathrm{E}-19$ & $3.26 \mathrm{E}-20$ & 3 & 31 & 66 \\
\hline \multicolumn{14}{|l|}{ 344-U1381C- } \\
\hline $4 \mathrm{H}-2$ & 30.00 & Silty clay & 74.9 & 0.11 & 0.14 & NT & 71.0 & 3 & $5.43 \mathrm{E}-17$ & $1.01 \mathrm{E}-19$ & 1 & 22 & 77 \\
\hline $4 \mathrm{H}-2$ & 30.00 & Silty clay & 74.9 & 0.11 & 0.34 & NT & 64.0 & 3 & $2.19 \mathrm{E}-17$ & $5.51 \mathrm{E}-20$ & 1 & 22 & 77 \\
\hline $4 \mathrm{H}-2$ & 30.00 & Silty clay & 74.9 & 0.11 & 0.55 & NT & 69.0 & 3 & $1.26 \mathrm{E}-17$ & 3.59E-19 & 1 & 22 & 77 \\
\hline $7 \mathrm{H}-4$ & 61.35 & Foraminiferal nannofossil-rich calcareous ooze with spicules & 80.6 & 0.24 & 0.21 & 98 & 78.0 & 4 & $1.26 \mathrm{E}-15$ & $8.89 \mathrm{E}-18$ & NT & NT & NT \\
\hline $7 \mathrm{H}-4$ & 61.35 & Foraminiferal nannofossil-rich calcareous ooze with spicules & 80.6 & 0.24 & 0.41 & 98 & 78.0 & 7 & $1.32 \mathrm{E}-15$ & $9.79 \mathrm{E}-18$ & NT & NT & NT \\
\hline $10 \mathrm{H}-3$ & 88.40 & Foraminiferal nannofossil-rich calcareous ooze with spicules & 78.3 & 0.32 & 0.14 & 90 & 77.0 & 3 & $8.78 \mathrm{E}-16$ & $3.20 \mathrm{E}-18$ & 5 & 25 & 70 \\
\hline $10 \mathrm{H}-3$ & 88.40 & Foraminiferal nannofossil-rich calcareous ooze with spicules & 78.3 & 0.32 & 0.34 & 90 & 78.0 & 3 & $5.55 \mathrm{E}-16$ & $1.42 \mathrm{E}-18$ & 5 & 25 & 70 \\
\hline $10 \mathrm{H}-3$ & 88.40 & Foraminiferal nannofossil-rich calcareous ooze with spicules & 78.3 & 0.32 & 0.55 & 90 & 78.0 & 3 & $4.50 \mathrm{E}-16$ & $1.29 \mathrm{E}-18$ & 5 & 25 & 70 \\
\hline \multicolumn{14}{|l|}{ 344-U1412C- } \\
\hline $6 \mathrm{R}-5$ & 344.29 & Clayey siltstone to claystone & 49.9 & 2.40 & 0.14 & NT & 49.0 & 3 & $3.99 \mathrm{E}-18$ & $2.64 \mathrm{E}-20$ & 3 & 27 & 70 \\
\hline $6 \mathrm{R}-5$ & 344.29 & Clayey siltstone to claystone & 49.9 & 2.40 & 0.34 & NT & 48.0 & 3 & $1.23 \mathrm{E}-18$ & $1.68 \mathrm{E}-20$ & 3 & 27 & 70 \\
\hline $6 \mathrm{R}-5$ & 344.29 & Clayey siltstone to claystone & 49.9 & 2.40 & 0.55 & NT & 47.0 & 3 & $6.30 \mathrm{E}-19$ & $1.46 \mathrm{E}-20$ & 3 & 27 & 70 \\
\hline \multicolumn{14}{|l|}{ 344-U1412D- } \\
\hline $3 R-4$ & 362.27 & Clayey siltstone to claystone & 49.3 & 2.53 & 0.21 & 92 & 48.0 & 3 & $8.28 \mathrm{E}-17$ & $1.20 \mathrm{E}-19$ & NT & NT & NT \\
\hline $3 R-4$ & 362.27 & Clayey siltstone to claystone & 49.3 & 2.53 & 0.41 & 92 & 47.0 & 3 & $7.81 \mathrm{E}-17$ & $1.06 \mathrm{E}-19$ & NT & NT & NT \\
\hline \multicolumn{14}{|l|}{ 344-U1413A- } \\
\hline $17 \mathrm{H}-1$ & 130.81 & Calcareous clayey silt/stone and minor sand/stone & 55.0 & 0.86 & 0.14 & 93 & 51.0 & 3 & 5.15E-17 & 4.61E-19 & 8 & 39 & 53 \\
\hline $17 \mathrm{H}-1$ & 130.81 & Calcareous clayey silt/stone and minor sand/stone & 55.0 & 0.86 & 0.34 & 93 & 55.0 & 3 & $1.75 \mathrm{E}-17$ & $7.85 \mathrm{E}-20$ & 8 & 39 & 53 \\
\hline $17 \mathrm{H}-1$ & 130.81 & Calcareous clayey silt/stone and minor sand/stone & 55.0 & 0.86 & 0.55 & 93 & 51.0 & 3 & $1.20 \mathrm{E}-17$ & $6.34 \mathrm{E}-20$ & 8 & 39 & 53 \\
\hline \multicolumn{14}{|l|}{ 344-U1413C- } \\
\hline $14 R-3$ & 298.68 & Calcareous clayey silt/stone and minor sand/stone & 44.6 & 2.43 & 0.21 & 93 & 43.0 & 5 & $1.75 \mathrm{E}-18$ & $6.00 \mathrm{E}-20$ & NT & NT & NT \\
\hline $14 \mathrm{R}-3$ & 298.68 & Calcareous clayey silt/stone and minor sand/stone & 44.6 & 2.43 & 0.41 & 93 & 42.0 & 4 & $1.41 \mathrm{E}-18$ & $7.16 \mathrm{E}-20$ & NT & NT & NT \\
\hline $30 \mathrm{R}-3$ & 452.99 & Fine to medium sandstone and siltstone & 41.9 & 3.86 & 0.14 & NT & 40.0 & 3 & $1.44 \mathrm{E}-18$ & $5.85 \mathrm{E}-20$ & 3 & 41 & 56 \\
\hline $30 \mathrm{R}-3$ & 452.99 & Fine to medium sandstone and siltstone & 41.9 & 3.86 & 0.28 & NT & 39.0 & 3 & $6.16 \mathrm{E}-19$ & $2.27 \mathrm{E}-20$ & 3 & 41 & 56 \\
\hline $30 \mathrm{R}-3$ & 452.99 & Fine to medium sandstone and siltstone & 41.9 & 3.86 & 0.41 & NT & 38.0 & 3 & $6.04 \mathrm{E}-19$ & $3.09 \mathrm{E}-20$ & 3 & 41 & 56 \\
\hline $41 \mathrm{R}-3$ & 559.61 & Fine to medium sandstone and siltstone & 39.5 & 4.88 & 0.14 & NT & 39.0 & 3 & $2.64 \mathrm{E}-18$ & $5.30 \mathrm{E}-20$ & 9 & 36 & 55 \\
\hline $41 \mathrm{R}-3$ & 559.61 & Fine to medium sandstone and siltstone & 39.5 & 4.88 & 0.28 & NT & 38.0 & 3 & $1.30 \mathrm{E}-18$ & $4.34 \mathrm{E}-20$ & 9 & 36 & 55 \\
\hline $41 \mathrm{R}-3$ & 559.61 & Fine to medium sandstone and siltstone & 39.5 & 4.88 & 0.41 & NT & 32.0 & 3 & $1.74 \mathrm{E}-18$ & $5.32 \mathrm{E}-20$ & 9 & 36 & 55 \\
\hline \multicolumn{14}{|l|}{ 344-U1414A- } \\
\hline $10 \mathrm{H}-1$ & 79.30 & Calcareous nannofossil-rich clay & 75.6 & 0.33 & 0.21 & 93 & 75.0 & 3 & $3.04 \mathrm{E}-17$ & $6.11 \mathrm{E}-20$ & 2 & 23 & 75 \\
\hline $10 \mathrm{H}-1$ & 79.30 & Calcareous nannofossil-rich clay & 75.6 & 0.33 & 0.41 & 93 & 75.0 & 3 & 2.97E-17 & $6.09 \mathrm{E}-20$ & 2 & 23 & 75 \\
\hline $19 \mathrm{H}-1$ & 163.41 & Nannofossil-rich calcareous ooze & 64.0 & 0.73 & 0.21 & 92 & 59.0 & 3 & $9.30 \mathrm{E}-18$ & $3.59 \mathrm{E}-20$ & NT & NT & NT \\
\hline
\end{tabular}




\begin{tabular}{|c|c|c|c|c|c|c|c|c|c|c|c|c|c|}
\hline \multirow{2}{*}{$\begin{array}{l}\text { Core, section, } \\
\text { interval }(\mathrm{cm})\end{array}$} & \multirow{2}{*}{$\begin{array}{c}\text { Top } \\
\text { depth } \\
\text { (mbsf) }\end{array}$} & \multirow[b]{2}{*}{ Lithostratigraphic unit description } & \multirow{2}{*}{$\begin{array}{l}\text { Shipboard } \\
\text { porosity } \\
\text { (\%) }\end{array}$} & \multirow{2}{*}{$\begin{array}{l}\text { Est. in situ } \\
\text { effective } \\
\text { stress } \\
(\mathrm{MPa})\end{array}$} & \multirow{2}{*}{$\begin{array}{l}\text { Effective } \\
\text { stress } \\
\text { during } \\
\text { testing } \\
\text { (MPa) }\end{array}$} & \multirow{2}{*}{$\begin{array}{l}\text { B-test } \\
\text { results } \\
(\%)\end{array}$} & \multirow{2}{*}{$\begin{array}{c}\text { Porosity } \\
\text { during } \\
\text { testing } \\
(\%)\end{array}$} & \multirow{2}{*}{$\begin{array}{l}\text { Number of } \\
\text { flow tests }\end{array}$} & \multirow{2}{*}{$\begin{array}{l}\text { Permeability } \\
\left(\mathrm{m}^{2}\right)\end{array}$} & \multirow{2}{*}{$\begin{array}{c}\text { Permeability } \\
\text { standard } \\
\text { deviation } \\
\left(\mathrm{m}^{2}\right)\end{array}$} & \multicolumn{3}{|c|}{ Grain size (wt\%) } \\
\hline & & & & & & & & & & & Sand & Silt & Clay \\
\hline $19 \mathrm{H}-1$ & 163.41 & Nannofossil-rich calcareous ooze & 64.0 & 0.73 & 0.41 & 92 & 58.0 & 3 & $8.99 \mathrm{E}-18$ & $3.58 \mathrm{E}-20$ & NT & NT & NT \\
\hline 36R-1 & 313.11 & Calcareous and siliceous cemented silt- and sandstone & 50.8 & 1.67 & 0.14 & 85 & 50.0 & 3 & $9.30 \mathrm{E}-17$ & $3.22 \mathrm{E}-18$ & 19 & 22 & 59 \\
\hline 36R-1 & 313.11 & Calcareous and siliceous cemented silt- and sandstone & 50.8 & 1.67 & 0.34 & 85 & 47.0 & 3 & 5.27E-17 & $1.48 \mathrm{E}-15$ & 19 & 22 & 59 \\
\hline 36R-1 & 313.11 & Calcareous and siliceous cemented silt- and sandstone & 50.8 & 1.67 & 0.55 & 85 & 47.0 & 3 & 7.06E-17 & 1.06E-15 & 19 & 22 & 59 \\
\hline $\begin{array}{r}44 \mathrm{R}-1 \mathrm{~W} \\
53-55\end{array}$ & 370.33 & Calcareous and siliceous cemented silt- and sandstone & 33.3 & 2.20 & 0.41 & 60 & 33.0 & 4 & $8.84 \mathrm{E}-18$ & $6.80 \mathrm{E}-20$ & NT & NT & NT \\
\hline
\end{tabular}

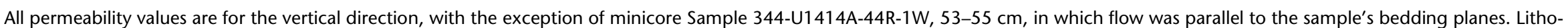
stratigraphic unit descriptions from Harris et al. (2013). NT = not tested. 